\title{
Development of a Tourist Route around the Mining Heritage of the Estremoz Anticline
}

\author{
Luís Lopes $^{1,2, a}$, Ruben Martins ${ }^{1,3, b}$, Patrícia Falé ${ }^{4, c}$, João Passos ${ }^{\mathrm{d}}$, \\ Francisco Bilou $^{5, e}$, Manuel Branco ${ }^{f}$ and Manuel Francisco Pereira ${ }^{1,6,9}$ \\ 1 Departamento de Geociências da Universidade de Évora, Portugal \\ ${ }^{2}$ Centro de Geofísica de Évora (CGE), FCT, Portugal \\ ${ }^{3}$ Centro de Investigação GeoBioTec, FCT, Portugal \\ ${ }^{4}$ Direcção Geral de Geologia e Energia (DGGE) \\ ${ }^{5}$ Câmara Municipal de Évora, Divisão de Promoção Turística \\ ${ }^{6}$ Instituto Dom Luiz \\ alopes@uevora.pt, ${ }^{b}$ rubenvm@uevora.pt, ${ }^{c}$ patricia.fale@dgge.pt, dj.jpassos@sapo.pt, \\ efrancisco.bilou@gmail.com, ${ }^{\mathrm{f}}$ manueljcbranco@gmail.com, ${ }^{9}$ mpereira@uevora.pt
}

Keywords: Cultural Heritage, Dimension Stones, Estremoz, Industrial Tourism, Marbles, Portugal

\begin{abstract}
The areas of the counties of Estremoz, Borba and Vila Viçosa, traditionally and since ancient times, have been a major region for extraction of marbles for use as a dimension stone in Portugal. The geological evolution of the Iberian Peninsula allowed the formation, in Alto Alentejo, of one of the World's most important and famous marble deposits. The Estremoz Anticline, about $42 \mathrm{~km}$ long and $8 \mathrm{~km}$ in maximum width, is an impressive place where the strength and ingenuity of Man has been used for decades to turn the "land upside down". The $27 \mathrm{~km}^{2}$ where the marble is concentrated is a place with a high density of quarries that have an unavoidable environmental impact, leaving stone exposed or accumulated in large tips, side-by-side with the Alentejo plains of wheat fields and olive trees. It is impossible to fully rehabilitate this area either for economic or strategic reasons, but it can be considered as resource for the promotion and development of industrial and scientific tourism and artistic and cultural events. A survey of the assets of the region has been undertaken and a wide variety of organizations and the industry are collaborating in planning a route and activities for the region.
\end{abstract}

\section{Introduction}

The development of an Industrial Heritage Route, or trail, around the Estremoz Anticline (now called "Rota Tons de Mármore") began in 2008 with an International Project: "Rutas Minerales da Iberoamérica y Ordenación Territorial, un Factor Integral para el Desarrollo Sostenible de la Sociedad - RUMYS", financed by the Ibero-American Program CYTED, Ciencia y Tecnologia para el Desarrollo. The purpose of this project was to promote investigations and develop proposals made by representatives from seven Latin American countries to secure cultural and international recognition for routes through mining areas.

More recently, a Project "Descobrir a Pedra Natural - Promoção do Turismo Industrial", through the "QREN, Sistemas de Apoio a Acções Colectivas (SIAC)" was approved and integrated into the Operational Plan INALENTEJO, Axis 1. This involves Tourism of Alentejo, (ERT - Regional Tourism Organization); as a promoter; the University of Évora - Geosciences Department, as scientific coordinator and DGEG (General Direction for Energy and Geology), LNEG (National Laboratory of Energy and Geology), counties of Sousel, Estremoz, Borba, Vila Viçosa and Alandroal, Fundação Obras, MEC - Momentos \& Eventos Culturais and several companies from the dimension stone industry, as principal partners [1].

The size and richness in mining heritage of the region is challenging and this can only be overcome by united efforts of various organizations and individuals, who have dedicated themselves to prolonged efforts to study, develop and promote this region in several economic and 